\title{
HTLV-I ASSOCIATED MYELOPATHY IN SALVADOR (NORTHEASTERN BRAZIL)
}

\author{
A. MEIRELES * - E. D. MOREIRA Jr.**- O.A. MORENO-CARVALHO***
}

R. BADARO ****-A. MELO *****

SUMMARY - Recent studies of tropical spastic paraparesis have confirmed the existence of human T-cell leukemia virus type-1 (HTLVI) in several tropical areas of the world. In order to determine the role of HTLVI as an etiologic agent of myelopathies in Salvador, we conducted a clinical and serological study in 43 patients with non-traumatic and non-tumoral myelopathies. We found 9 patients with HTLVI associated myelopathy (HAM) which points to a new endemic area of HAM.

KEY WORDS: HTLVI, myelopathy, tropical spastic paraparesis.

Mielopatia associada a HTLV-I em Salvador

RESUMO - Recentes estudos têm mostrado la presença de mielopatia associada a infecçăo por HTLV-I em muitas áreas tropicais do mundo. Com o objetivo de determinar o papel do HTLV-I como agente etiológico de mielopatias em Salvador, realizamos estudo clínico e sorológico em 43 pacientes com mielopatia de etiologia não traumática e năo tumoral. Encontramos 9 piacientes com mielopatia associada a HTLV-I (HAM) o que sugere nova área endêmica de HAM.

PALAVRAS-CHAVE: HTLV-I, mieiopatia, paraparesila espástica tropical.

Human T-lymphotropic virus type one (HTLVI) is associated with aduit T-cell leukemia/lymphoma (ATL) and tropical spastic paraparesis. HTLVI associated myelopathy (HAM) has been described in southern Japan, USA, Colombia and Central Africa 6,8,9, In Brazil, several cases have been described in Ceará 2, Rio de Janeiro, 2,4, São Paulo 1 , and Bahia 5 showing the association of myelopathy and HTLVI. In a recent study Moreira Jr. \& col. 5 described a high prevalence of HTLVI infection in several risk groups and in a randomized group of 129 patients admitted to a hospital which cares for the low socio-economic class. It was found a prevalence of $19,4 \%$ for HTLVI in the serum of these patients.

The first cases of HAM in Bahia are described in this paper.

\section{METHODS}

Sera and CSF of 43 patients admitted in a general hospital in Salvador in a period of 5 months with chronic spastic paraparesis were tested for HTLVI. Nine patients with progressive chronic spastic paraparesis had serum and CSF positive to HTLVI.

Antibodies to HTLVI were detected with a commercially available enzyme immunoassay (EIA). EIA repeatedly reactive samples were further confirmed by a new dot blot confirmatory immunoassay using highly purified HTLVI viral and recombinant proteins as an

Santo Antonio Hospital (HSA) and Federal University of Bahia (UFBA), Salvador: * HSA; ** UFBA; **** Santo Amaro Hospital, Salvador; **** UFBA and Cornel University Medical College, New York; ***** HSA and UFBA.

Dr. Ailton Melo - Departamento de Ciencias da Biorregulação, Instituto de Ciencias da Saúde, UFBA - Av. Reitor Miguel Calmon $s / n$ - 40120 Salvador BA - Brasil. 
antigen source. Samples were considered positive if antibodies against the both gag (p24) and env (p21E) gene products were present. In CSF samples patterns considered were: cytology (cells/mm3 number and cytomorphological profile), protein and glucose contents (mg/dL), and gamma globulins. participation $(\%)$ and distribution on the protein profile. Other specific antibodies to syphilis, cysticercosis, schistosomiasis, toxoplasmosis and HIV were also tested.

\section{RESULTS}

All the patients were adult, with ages that range from 18 to 56 years. Two of the patients were promiscuos and one of them had blood transfusion 8 months before symptoms. They had similar histories with progressive weakness, first in one leg and after in the other leg, that was associated with paresthesias of several degrees of intensity. None of the patients had sensory level. All of them had vegetative disturbances that where characterized by bladder dysfunction (manifested by increase urinary urgence or incontinence), constipation and impotence in men.

CSF showed slight increase in the cell number with $a_{4}$ range of 4.3 to 25 cells $/ \mathrm{mm} 3$ with predominance of lymphocytes and monocytes. There was no relevant number of macrophages, eosinophils and neutrophils. The glucose was normal and the protein ranged from 28 to $68 \mathrm{mg} / \mathrm{dL}$. There was a slight increase in gamma-globu'in rate in two of them. One patient had infection by HIV and HTLVI. No other associated parasite or fungus infections were found.

\section{COMMENTS}

In recent years, many studies have shown the high prevalence of HTLVI infection and HAM among different races and high risk groups in several populations in the world 8 . In Brazil, Costa \& col.3 reported 10 patients with clinical evidence of TSP and Cortes \& col. 2 concluded that HTLVI was prevalent in groups at risk for AIDS. Our cases confirm former results of HAM in Brazil and points to an endemic zone of HTLVI associated myelopathy. Among the patients studied two were promiscuous and only one had received blood transfusion suggesting a vertical source of contamination.

As has been pointed out by Spina-França \& col.10, we also found a slight increase in the cell number as well as in the protein content and gamma globulins rate in the $\mathrm{CSF}$.

Since we have in Salvador a population descendent from black Africans and lbericans this endemia could result from this migration. However, further studies are necessary to assess this question.

\section{REFERENCES}

1. Castro LHM, Chaves CJ, Callegaro D, Nobrega JPS, Scaff M. HTLV-1 associated myelopathy in Brazil: a preliminary report. Arq. Neuropsiquiat 1989, 47:501-502.

2. Cortes E, Detels R, Aboulafia D, Li XL, Moudgil $T$, Alan M, Bonecker C, Gonzaga A, Oyafuso L, Tondo M, Boite C, Hammaershlak N, Capitani C, Slamon DJ, Ho DD. HIV-1, HIV-2 and HTLV-1 infection in high-risk groups in Brazil. $N$ Engl $J$ Med 1989, 320: 953-958.

3. Costa CMC, Saligueiro MR, Carton H, Vale OC, Arruda AM. Tropical spastic paraparesis in northeastern Brazil. Arq Neuropsiquat 1989, 47:134-138.

0. Lee H, Anderson E. Alain JP, Gonzaga, A. HTLV-1 infection in Brazil. Blood 1989, $73: 1742$.

5. Moretra ED Jr, Harrington W Jr, Ribeiro T, Brites C, Melo A, Swanson P, Lee H, Badaro R. HTLV-II and a new endemic area for HTLV-I in Brazil (in press).

6. Osame M, Igata A, Matsumoto, M. HTLV-I associated myelopathy, a. new clinical entity. Lancet 1986, 1:1031-1032.

7. Roman GC, Roman LN, Spencer PS, Schoenberg BS. Tropical spastic paraparesis: a neuroepidemiological study in Colombia. Ann Neurol 1985, 17:361-365.

8. Roman GC. The neuroepidemiology of tropical spastic paraparesis. Ann Neurol 1988, 23 (Suppl):113-130.

9. Sheremata WA, Quencer R, Gatti E, Freitas E, Harper M, Koprowski H. Magnetic resonance imaging of tropical spastic paraplegia. Neurology 1987, 374 (Suppl 1):322.

10. Spina-França A, Livramento JA, Machado LR, Gomes HR, Vianna LS, Castro LHM, Nobrega JPS, Bacheschi LA. HTLV-1 antibodies in serum and cerebrospinal fluid in tropical spastic paraparesis in Brazil. Arq Neuropsiquiat 1990,48:441-447. 